\title{
A Critical Edition of LitTLE JoHN's ANSWER to RoBin Hood AND tHe DUKE OF
}

$$
\text { LANCASTER (1727) }{ }^{1}
$$

\author{
Stephen Basdeo \\ Richmond University (Leeds RIASA)
}

In 1733 the Tory statesman Henry St. John, Viscount Bolingbroke, wrote in The Craftsman that:

When the people find themselves generally aggrieved, they are apt to manifest their resentment in satirical ballads, allegories, by-sayings, and ironical points of low wit. They sometimes go farther, and break out into hieroglyphical expressions of their anger against the person, whom they conceive to be the projector of any injury done, or intended to be done them. ${ }^{2}$

Bolingbroke was correct in his observation. The eighteenth century was a golden age for satire. From the Augustan satire of Joseph Addison (1676-1719) and Richard Steele (16761729), to the frequently grotesque prints of the latter half of the period, ${ }^{3}$ it seemed that no one and nothing in public life was exempt from being critiqued. In the early part of the century, a common target of these satirical attacks was politicians, in particular the Whig Prime Minister, Robert Walpole (1676-1745). It is Walpole, Bolingbroke, and other members of the political establishment who are targeted in the ballad Little John's Answer to Robin Hood and the Duke of Lancaster (1727) that is discussed here.

Despite R. B. Dobson and J. Taylor's assertion that "the day has long since past when the student of English popular literature could hope for the discovery of a genuinely new Robin Hood ballad," 4 Little John's Answer was only brought to the attention of Robin Hood scholars in 2015. I located the ballad in the Special Collections Archive of the University of Leeds ${ }^{5}$ after having read a footnote in the work of an early twentieth-century scholar, Milton Percival. In his anthology Political Ballads Illustrating the Administration of Sir Robert Walpole (1916), he includes the ballad Robin Hood and the Duke of Lancaster (1727). He was aware of Little John's Answer, although it is unclear whether he actually saw it, and simply commented in his footnote that it was "a Grub Street version of [Robin Hood and the Duke of Lancaster]." 78 It is my pleasure, therefore, to present readers with an edited version

\footnotetext{
${ }^{1}$ Acknowledgments: I would like to thank Alexander L. Kaufman and Valerie B. Johnson for their support in preparing this article, as well as the anonymous reviewer whose helpful comments strengthened this paper.

2 Henry St. John, Viscount Bolingbroke, The Craftsman, 10 Feb. 1733, cited in Kathleen Wilson, The Sense of the People: Politics, Culture and Imperialism in England, 1715-1785, Past and Present Publications (Cambridge: Cambridge University Press, 1998), 27.

${ }^{3}$ See Vic Gatrell, City of Laughter: Sex and Satire in Eighteenth-Century London (London: Atlantic Books, 2007).

${ }^{4}$ R. B. Dobson and J. Taylor, ed., Rymes of Robyn Hood: An Introduction to the English Outlaw, 3rd ed. (Stroud: Sutton Publishing, 1997), xiv.

${ }^{5}$ Little John's Answer to Robin Hood and the Duke of Lancaster. A Ballad. To the Tune of The Abbot of Canterbury (London: T. White, Chancery Lane, 1727), 4pp. Leeds, Brotherton Library BC Lt q/WAL/L.

${ }^{7}$ Grub Street was in the vicinity of Moorfields in London and was known as the residence of a number of publishers of penny pamphlets and satires but, according to Pat Rogers, the street soon acquired a reputation for
} 
of Little John's Answer to Robin Hood and the Duke of Lancaster. In this edition, the spelling, italicisation, and capitalisation of the original have been retained, with the exception of the long $s$ letterform. Brief footnotes have also been added to the ballad explaining and offering suggestions as to the meaning of some of the allusions within the text.

Little is known of the author of this ballad due to the fact that whoever wrote it chose to remain anonymous, a practice that was adopted by many satirists during the eighteenth century. Perhaps some brief biographical information can be suggested for the man who printed it instead. The ballad was printed by T. White of Chancery Lane in London. There is a Thomas White listed as an apprentice to the printer James Hayward in 1718 some years before the ballad's publication, according to The British Book Trade Index. ${ }^{9}$ Given that this appears to be the only man with the initial of T. and the surname of White in the records of the publishing trade, it is not unreasonable to suppose that this is the same man who later printed Little John's Answer. A printer named T. White-perhaps the same-was also active in 1736 as there is another publication bearing this imprint appearing in that year. ${ }^{10}$ Apprenticeship during the eighteenth century usually began when a person was around 12 or 13 years of age, ${ }^{11}$ and generally lasted until a person was 24 years old. ${ }^{12}$ The absence of a printer named T. White from Henry L. Plomer's A Dictionary of all the Booksellers Who Were at Work in England, Scotland, and Ireland between 1688 and 1725 (1922), indicates that, if indeed all of these people named T. White are the same person, he must have ended his apprenticeship and set up his own printing establishment after 1725 . $^{13}$ Thus a tentative biographical outline for the printer T. White can be traced. He would probably have been born between 1701 and 1703. He was then apprenticed to Hayward in 1718, and finished his apprenticeship between 1725 and 1727. By 1727 he had set up on his own publishing house, and was still active until at least 1736. These admittedly scant biographical details rest, of course, on the supposition that all of these people with the surname White are the same person, and therefore the foregoing details must be taken as suggestive rather than as a statement of historical truth.

The ballad itself is a clear product of the eighteenth century when the lives of criminals were frequently appropriated by satirists and playwrights and equated with political figures. The character of Peachum is used in The Beggar's Opera (1727), for instance, to

producing "low" literature, so that the actual Grub Street in time gave rise to a metaphor denoting the essentially ephemeral production of the literary hack. See Pat Rogers, Hacks and Dunces: Pope, Swift, and Grub Street, 2nd ed. (London: Methuen, 1980), 18-19.

${ }^{8}$ Milton B. Percival, Political Ballads Illustrating the Administration of Sir Robert Walpole (Oxford: Clarendon Press, 1916), 183.

${ }^{9}$ Mike Parry, “Thomas White,” British Book Trade Index

http://www.bbti.bham.ac.uk/Detailswithsource.htm?TraderID=94262 accessed October 13, 2015.

${ }^{10}$ A catalogue and particular description of the human anatomy in wax-work, and several other preparations to be seen at the Royal-Exchange (London: T. White, 1736).

11 Tim Hitchcock, Sharon Howard, and Robert Shoemaker, “Apprenticeship Indentures and Disciplinary Cases (IA),” in London Lives, 1690-1800, www.londonlives.org, accessed October 14, 2015.

12 Joan Lane, Apprenticeship in England, 1600-1914 (London: University College London Press, 1996), 7.

${ }^{13}$ Henry R. Plomer et al., A Dictionary of all the Booksellers Who Were at Work in England, Scotland, and Ireland between 1688 and 1725 (Oxford: Printed for the Bibliographical Society, 1922), 308-10. 
satirise Walpole (1676-1745). Peachum is a thief taker ${ }^{14}$ who places his profession on a par with contemporary politicians by saying, “'tis but fitting we should protect and encourage cheats, since we live by 'em." 15 References to criminals whose names were derivatives of Robert abound in Gay's play, such as, "Robin of Bagshot, alias [...] Bob Booty." 16 Walpole was colloquially named Robin in satirical pamphlets such as Robin's Reign, or Seven's the Main (1731), ${ }^{17}$ and Robin and Will (1731). ${ }^{18}$ Furthermore, out of the alley-ways and courts of the area around Grub Street, where many hack writers lived and worked, numerous pamphlets poured forth attacking the "Robinocracy."19 The novelist Henry Fielding (17071754) frequently referred to "Roberdsmen" in his writings, a term which carried allusions both to Robin Hood's gang and Walpole and his men. ${ }^{20}$ Fielding's novel Jonathan Wild (1743) — an embellished biography of the eponymous thief taker-has been interpreted by critics as a satire upon Walpole. ${ }^{21}$ As we can see, Walpole was equated with criminals on various occasions, ${ }^{22}$ which is the case in Little John's Answer where he is represented by Robin Hood. Despite the efforts of satirists to expose him as corrupt, however, Walpole held a firm grip on power during his tenure as Prime Minister, which lasted between 1721 and 1742.

The ballad reads as though it is a sequel to the legend of Robin Hood. The year is 1202 and Robin has received a royal pardon and has become the king's "keeper." It is implied that he has become one of the most corrupt of the king's servants, and so the Duke of Lancaster travels to meet with the king and expose Robin's corruption. When the Duke meets the king, he pours forth a number of accusations against Robin. King John, however, is

\footnotetext{
${ }^{14}$ Before the establishment of a professional police force in 1829, law enforcement was carried out in an often haphazard manner by watchmen, parish constables, and thief takers. The latter were individuals who were hired by the victims of a crime to recover their stolen goods. The post was open to corruption and the most famous thief taker was Jonathan Wild (1683-1725). See Lucy Moore, The Thieves’ Opera (London: Penguin, 1997).

15 John Gay, The Beggar's Opera. As it is Acted at the Theatre Royal in Lincolns-Inn-Fields (London: John Watts, 1727), 1.

${ }^{16}$ Gay, The Beggar's Opera, 3.

${ }^{17}$ Robin's Reign; or, Seven's the Main (London: Sold by the Printsellers of London and Westminster, 1731), London, British Museum BM Satires 1868,0808.3541, http://www.britishmuseum.org/research/collection_online/collection_object_details.aspx?objectId=1572165\&pa rtId=1

${ }^{18}$ Robin and Will; or, The Millers of Arlington. A New Ballad. (London: Printed for W. Webb, near the RoyalExchange; and sold by the booksellers of London and Westminster, 1733), 7pp. Bodleian Library Broadside Ballads Bod4943, http://ballads.bodleian.ox.ac.uk/view/edition/4943.

${ }^{19}$ Paul Langford, The Eighteenth Century: A Very Short Introduction (Oxford: Oxford University Press, 2000), 22.

20 J. A. Downie, A Political Biography of Henry Fielding (London: Routledge, 2009), 92.

${ }^{21}$ This view has persisted since 1858 with Keightley’s essay “On the Life and Writing of Henry Fielding.” More recently, however, Downie has nuanced this view, pointing out that some scholars argue that while the original edition of Jonathan Wild makes allusions to the "Great Man” (Walpole), late editions which Fielding amended are principally a satire on false greatness. Downie's also points to the fact that Walpole subscribed to ten sets of Fielding's Miscellanies, and near the end of his life, Fielding described Wild as "one of the best of men and ministers.” See Downie, A Political Biography of Henry Fielding, 126-27.

${ }^{22}$ Ibid.
}

The Bulletin of the International Association for Robin Hood Studies 1 (2017): 15-31. 
perfectly acquainted as to the nature of Robin's character, and the way that he manages state affairs. He dismisses the duke's concerns, admitting that retaining Robin as his keeper is merely a matter of selecting the best out of a number of bad candidates for the position. The question is not whether Robin Hood is a corrupt minister of state, but who would replace him and be less corrupt. In fact, the King is dismayed with the Duke for bringing the matter of Robin's alleged corruption to his attention, and John asks the Duke of Lancaster if he would undertake the office of keeper, to which the Duke simply remains silent.

In Little John's Answer, King John stands in for King George I, and Robin Hood is Walpole. The Duke of Lancaster represents Nicholas Lechmere (1675-1727). ${ }^{23}$ Lechmere was a Whig politician and a lawyer, who is described as having been stubborn, haughty, and opinionated, often engaging in frequent clashes with Walpole in the Commons. ${ }^{24}$ The narrative of the ballad refers to events which occurred between the King, Walpole, Lechmere, and Bolingbroke in 1727. Before discussing the events of 1727, however, it is necessary to provide some background information. Bolingbroke had been forced to flee from England to France in 1715, an event which was gleefully reported in another ballad entitled Advice to Dr. Harry Gambol (c.1715?). ${ }^{26}$ "Harry Gambol" was a contemporary sobriquet given to Bolingbroke (1678-1751). ${ }^{27}$ The Whigs had won the general election in the previous year, and upon taking office they accused many Tory members of the previous administration of corruption, and began to have some of them impeached. Bolingbroke was one of their targets. ${ }^{28}$ During his exile in France, Bolingbroke made the mistake of accepting an Earldom from the Pretender, James Stuart (1688-1766), and agreed to serve as the exiled James' Secretary of State. ${ }^{29}$ After the disastrous Jacobite Rising in 1715, however, James blamed Bolingbroke for its failure, and consequently Bolingbroke secretly made contact with the British Ambassador in Paris to betray the Jacobite cause in return for a royal pardon. ${ }^{30} \mathrm{He}$ was eventually allowed to return to England and was pardoned on 25 May 1723, though he was still subject to some penalties, such as a prohibition from taking up his seat in the House of Lords. ${ }^{31}$

In April 1721 Walpole became Prime Minister and firmly established his power in the Commons by making himself indispensable to George I. He kept a close eye on all levels of

${ }^{23}$ Nicholas Lechmere was Chancellor of the Duchy of Lancaster and, hence, "the Duke of Lancaster" in the ballad; Dobson and Taylor, Rymes of Robyn Hood, 192.

24 A. A. Hanham, "Lechmere, Nicholas, Baron Lechmere (1675-1727)," Oxford Dictionary of National Biography (Oxford: Oxford University Press, 2004),http://www.oxforddnb.com/view/article/16262, accessed April 4, 2015.

${ }^{26}$ Advice to Dr. Harry Gambol, upon the pulling down of his stage, given by his abused patient (London: Printed for A. B---tr, one who has had expensive Experience of the Doctor's Barbarous Practice, c.1715?), Bodleian Library Broadside Ballads Bod16306.

${ }^{27}$ Tone Sundt Urstad, Sir Robert Walpole's Poets: The Use of Literature as Pro-government Propaganda, 17211742 (Newark: University of Delaware Press, 2000), 207.

${ }^{28}$ H. T. Dickinson, “St John, Henry, styled first Viscount Bolingbroke (1678-1751),” in The Oxford Dictionary of National Biography (Oxford: Oxford University Press, 2004) http:/www.oxforddnb.com/view/article/24496. Accessed April 8, 2015.

29 Ibid.

${ }^{30}$ Ibid.

${ }^{31}$ Ibid. 
government, frequently attending sittings, and critically judging the mood of the MPs to allow for tactical retreats on certain policy issues when required. ${ }^{32} \mathrm{He}$ also extended his power by expanding his system of patronage, carefully presiding over government appointments in the hope of forming a cohort of men that he could depend upon. By 1727 there were 150 of his men in the Commons. ${ }^{33}$ Despite the allegations of corruption levelled at him by his opponents, especially in regard to his handling of the economic crash known as the South Sea Bubble in 1720, he was a shrewd political operator. By 1727, when Little John's Answer was published, one early and admittedly very admiring biographer of Walpole stated that he now "stood in the highest estimation of king and nation." 34

In 1727 Bolingbroke approached the Duchess of Kendal (1667-1743) — the King's mistress - to effect the full restitution of his rights and privileges. The Duchess was dismissed outright by the King, and it seemed that Bolingbroke would not achieve the restitution he desired. An unlikely ally in this matter was Walpole, who said he would intercede on Bolingbroke's behalf:

At a proper interval, Walpole besought the king to grant an audience to Bolingbroke; and urged the propriety, by observing, that if this request was rejected, much clamour would be raised against him for keeping the king to himself, and for permitting none to approach his person who might tell unwelcome truths. ${ }^{35}$

The king relented and Bolingbroke was granted an audience and admitted into the King's apartment at Walpole's behest. Meantime, Lechmere had learned news of the intended meeting between Bolingbroke and the King, and strongly disapproved. He disliked Walpole, and, thinking that Walpole was arranging the meeting to invite Bolingbroke to serve in the government, took it upon himself to approach the King and "expose” this apparent plot between Walpole and Bolingbroke. Lechmere travelled to see the king upon a flimsy pretence of asking him to sign some documents, hence the words in the ballad: "A very fine story he had to relate, / He had something in Hand, and more in his Pate." 36 Upon enquiring to see the King, Lechmere was told that he must wait, for the King was with Bolingbroke in his apartment, and that Walpole was also waiting in the adjoining apartment to see the King afterwards. Bolingbroke finished his interview at that moment and exited the King's apartment. Then the following scene occurred:

Lechmere instantly rushed into the closet, and without making any apology, or entering upon his own business, burst out into the most violent invectives against Walpole, whom he reviled as not contented with doing mischief himself, but as having introduced one [Bolingbroke] who was, if possible worse than himself, to be his assistant. ${ }^{37}$

Lechmere had completely misunderstood the situation, and the King decided to have a joke at his expense: "the King, delighted with this mistake, calmly asked him, if he would undertake

\footnotetext{
32 Julian Hoppit, A Land of Liberty? England, 1689-1727 (Oxford: Oxford University Press, 2000), 409.

${ }^{33}$ Ibid.

${ }^{34}$ William Coxe, Memoirs of the Life and Administration of Sir Robert Walpole, Earl of Orford (1798; repr. London: Longman, 1816), 250.

${ }^{35}$ Coxe, Memoirs, 252-53.

${ }^{36}$ Little John's Answer, 3.

${ }^{37}$ Coxe, Memoirs, 253.
} 
the office of Prime Minister, Lechmere made no reply, but continued pouring forth his invectives, without having offered any of [his] papers to sign.”38 Afterwards Walpole, upon seeing the King thus amused, enquired as to the reason why, to which the King simply responded, "Bagatelles! Bagatelles!”39

It might be assumed that this event between George I, Walpole, Bolingbroke, and Lechmere, and the ballad that relates this event, is no more deserving of a place in history than a humorous footnote. This ballad, however, is valuable to both Robin Hood scholars and eighteenth-century researchers. There was a multitude of political satires produced during Walpole's tenure as Prime Minister. But whilst elite opposition to Walpole's regime-from the writings of Alexander Pope, ${ }^{40}$ Jonathan Swift, ${ }^{41}$ John Gay, ${ }^{42}$ and Henry Fielding ${ }^{43}$ - is a topic which has been discussed at length, ${ }^{44}$ popular participation in the political discourse of the day is a subject which has not yet been explored at any length. ${ }^{45}$ These popular contributions to the contemporary political debate often took the form of ballads such as Little John's Answer, or "satirical ballads, allegories, and by-sayings." 46 Thus Little John's Answer is part of the extra-parliamentary contribution to eighteenth-century politics, satirising those at the heart of the political establishment.

It is only King John who emerges with a relatively untarnished reputation in the ballad. Robin is depicted as embezzling and corrupt; Lancaster is silly and impetuous; Gambol is no better, being "a sinner." ${ }^{47}$ Whilst Walpole is certainly criticised in the ballad, it is insufficient to dismiss this satire solely as a critique of Walpole. The author appears to be commenting upon corruption that is at the heart of the eighteenth-century political establishment. As mentioned earlier, the author acknowledges that were the King to replace Walpole, other ministers such as Lechmere would also be corrupt. This ballad, then, appears to be part of a widespread press-driven critique of authority which spread beyond elite writers and made it into the popular culture of the day. ${ }^{48}$ The blame for national, social, and moral

\footnotetext{
${ }^{38}$ Coxe, Memoirs, 254.

${ }^{39}$ Ibid.

${ }^{40}$ See Howard Erskine-Hill, "Pope and the Poetry of Opposition," in The Cambridge Companion to Alexander Pope, ed. Pat Rogers (Cambridge: Cambridge University Press, 2007), 134-49.

${ }^{41}$ See Dustin Griffin, Swift and Pope: Satirists in Dialogue (Cambridge: Cambridge University Press, 2010) and David Oakleaf, A Political Biography of Jonathan Swift (London: Pickering and Chatto, 2008).

42 See John Richardson, “John Gay, The Beggar's Opera, and Forms of Resistance,” Eighteenth-Century Life 24, no. 3 (2000): 19-30.

43 See Thomas R. Cleary, Henry Fielding: Political Writer (Waterloo, ON: Wilfrid Laurier University Press, 1984) and Downie, A Political Biography of Henry Fielding.

${ }^{44}$ For a general overview of eighteenth-century satire, see Howard D. Weinbrot, Eighteenth-Century Satire: Essays on Text and Context from Dryden to Peter Pindar (Cambridge: Cambridge University Press, 1988), and the older yet still informative work is Bertrand A. Goldgar, Walpole and the Wits (Lincoln, NE: University of Nebraska Press, 1976).

${ }^{45}$ Wilson, The Sense of the People, 5.

${ }^{46}$ Bolingbroke, The Craftsman.

47 "Robin Hood and the Duke of Lancaster," 400.

${ }^{48}$ Other examples of anti-Walpole ballads exist such as: The congress of excise-asses. Or Sir B---ue S---ng's overthrow: a new ballad (London: Printed for Mr. Nichols, and sold at the pamphlet shops, 1733), 8pp. Bodleian Library Broadside Ballads Bod6078; The knight and the prelate: a new ballad (London: Printed for P.
} 
ills was laid at the feet of members of the political establishment by anonymous writers who contributed to the extra-parliamentary political discourse. ${ }^{49}$ This critique of authority was driven by the press in the emergent public sphere, in which social spaces such as the coffeehouse, along with the publication of printed matter, created a "marketplace" where ideas and gossip could be discussed and debated outside of the confines of the royal court. ${ }^{50}$ The ballad's attack on both Whig and Tory politicians serves to remind eighteenth-century scholars that opposition to the eighteenth-century political establishment need not always be divided along party lines. ${ }^{51}$

The format of the ballad suggests that it was designed for readers, rather than part of an oral or popular tradition. It takes the form of a folio size four page pamphlet. Combined with its reference to "gentle readers" 52 and its political content, the events detailed in the ballad were more than likely intended to be read and debated within social spaces such as the coffeehouse. ${ }^{53}$ A further indication that this ballad is aimed at a sophisticated and politically informed audience is that fact that, at four pence, it was more expensive than an average broadside ballad which typically sold for a penny or less; even a half-penny ballad was "beyond the purse of poorer people." 54

For Robin Hood scholars, the ballad confirms that Robin Hood's status as a hero, in the conventional sense of the word, was by no means assured during the eighteenth century. A “robbing” and allegedly corrupt Prime Minister, colloquially named Robin, was easily equated with the highwayman of medieval legend. One anonymous writer in 1737 drew an explicit comparison between Robin Hood and those in "civil employments." The author further suggests that, had Robin Hood taken inspiration from men such as Walpole, or those in "civil employments," no one would have ever heard of his crimes, statesmen are rob people and escape unimpeached:

Had [Robin Hood] turn'd his head to politics, had he been placed in the finances, or promoted to the station of Paymaster, Receiver General, Treasurer [...] and robb'd the Exchequer, as Falstaff says, with unwash'd hands; had he plunder'd the publick, in a civil employment, till he had been almost the only rich man in the kingdom, we may conclude from many passages of history that there would have been no signs of him at this day. ${ }^{55}$

\footnotetext{
Holder, near St. James's, 1734) Bodleian Library Broadside Ballads Bod23066; Bambridge and H---g---ns's petition to a certain great knight (London: Prinded [sic] for J. Thompson, near the Std, c.1730?) Bod16296. Examples of ballads censuring Bolingbroke include A hue and cry after the Lord B---k or Young Perkin glad to see his friends (London: London; Printed in the year 1715) Bodleian Library Broadside Ballads Bod6404.

${ }^{49}$ Wilson, The Sense of the People, 26.

50 See Jurgen Habermas, The Structural Transformation of the Public Sphere: An Inquiry into a Category of Bourgeois Society, trans. Thomas Burger and Frederick Lawrence (Cambridge: Polity, 2002).

${ }^{51}$ Wilson, The Sense of the People, 14.

${ }^{52}$ Little John's Answer, to Robin-Hood and the Duke of Lancaster. A Ballad, To the Tune of The Abbot of Canterbury (London: T. White, 1727), 3.

53 See Habermas, Structural Transformation, and more recently Brian William Cowan, The Social Life of Coffee: The Emergence of the British Coffeehouse (New Haven: Yale University Press, 2005).

${ }^{54}$ Leslie Shepherd, The History of Street Literature (Newton Abbot: David Charles, 1973), 25.

55 “Bravery: The Characteristic of an Englishman,” The Gentleman's Magazine and Historical Chronicle, No. 8, June 1738, 300.
} 
The references to various government positions such as Paymaster, Receiver General, and Treasurer are reminiscent of the words of Peachum the Thief Taker's song in The Beggar's Opera in which the thieves and whores of 'low life' are equal in morals to those of more elevated status:

Through all the Employments of Life

Each Neighbour abuses his Brother;

Whore and Rogue they call Husband and Wife:

All Professions be-rogue one another:

The Priest calls the Lawyer a Cheat,

The Lawyer be-knaves the Divine:

And the Statesman, because he's so great,

Thinks his Trade as honest as mine. ${ }^{56}$

As a sequel to the legend, Little John's Answer appears to anticipate William M. Thackeray's Ivanhoe sequel, Rebecca and Rowena (1850), in which "the Earl of Huntingdon was a very different character from Robin Hood the Forester," who has become a fat and very mean, hard-hearted magistrate, and sends "scores of poachers to Botany Bay." 57 There is an undercurrent in the Robin Hood tradition of texts such as Little John's Answer that resist the trend towards gentrification. Thus ballads such as Little John's Answer allow Robin Hood scholars to chart the highs and lows in the course of the legend's gentrification.

This is the first time that Little John's Answer has appeared in print, owing to the fact that it has only recently been brought to light. For Robin Hood scholars it means that there is now an additional ballad that can be added to the Robin Hood canon. Yet whilst Little John's Answer is a relatively recent ballad, dating from 1727, the fact that new texts can resurface, even in 2015-after almost 250 years of various antiquaries' and historians' efforts in uncovering material relating to the Robin Hood legend-holds out the tantalising possibility that other, perhaps even older, texts may have gone unnoticed and may also resurface in the future.

\footnotetext{
${ }^{56}$ Gay, The Beggar's Opera, 1.

${ }^{57}$ William Makepeace Thackeray, Rebecca and Rowena (London: Hesperus, 2002), 13-14.
} 
Little John's Answer, to ROBIN-HOOD and the Duke of Lancaster. A Ballad, To the Tune of The Abbot of Canterbury.

LONDON: Printed by T. White, in Chancery Lane, 1727.

\section{[Price 4d.]}

Here's a story reviv'd from twelve hundred \& two, Of bold Robin-Hood, but I know not how true; How the Duke of Lancashire came to King John, To tell of things in his Kingdom was done.

What could be the meaning, this bold little Duke,

Did ride in such hast, with his liege to dispute;

To foam at the Mouth, it shewed Malice and Spleen;

showed

Search out, gentle Reader, what can all this mean?

Derry down \&c.

The terrible Knock, which he gave at the Gate,

Was not half so hard, as his Heart that did beat,

Least his Viset, so hastly, don't answer his End,

What he had to say, he therefore had Pen'd.

Visit; hastily

15 Derry down, \&c.

The Porter affronted, he spoke very stern,

His Business he therefore wanted to learn;

My Business is with King John, quoth the Duke,

And you've no Reason, the same to dispute.

20 Derry down, \&c.

I've the Message in Hand, and my Liege I must see, You shall be admitted then immediately:

A very fine story he had to relate,

He had something in Hand, and more in his Pate.

head

25 Derry \&c.

The bold little Duke, push'd on with desire, Of raising a States-Man, still higher and higher, And turn Robin out in a Woeful Condition; For tho' he's a Lawyer, he's no Politician. Derry \&c.

He told the good Yeoman, that he was a Peer; Admitted, away to King John he did steer, To free him from Vermin, as he did pretend, 
But he that speaks fair, is not always a Friend.

Derry, \&c.

The Dwarf, that was trimming the Beard of the King,

Did start, for to see his Stature come in,

Much more for to see him so foam in a Per,

My Liege was surpriz'd, to see him a Sweat.

40 Derry, \&c.

Then soon the Duke, his Tale did begin, How bold Robin-Hood, did abuse his good King, By keeping his Subjects, inclos'd in a Wood, enclosed Says my Liege, to himself, Would you be Robin-Hood?

45 Derry, \&c.

He complained how Bold Robin did kill the King's Deer, But nothing he had said, had he shar'd of the Cheer; If the little Duke, could but share of the Fees, He'd never have said nothing, let who would keep the Keys.

50 Derry, \&c.

This thing it is Robbing, the Law does direct;

But Thieves and Receivers, are much of a Sect, But Robin-Hood's Cunning, he none of the Gang, Was there none to impeach, there's none could be Hang'd.

55 Derry, \&c.

Says my Liege, should I make Harry Gambol a Keeper, I do not think that the Plot it could never be deeper; My Court, when he comes, shall ne'er be much thinner, For I'll keep him out, sir, as I am a Sinner.

60 Derry, \&c.

Should I turn Robin out, that would not be all, You tell me, You would have no Robbing at all:

But Robin will Robb, do all that you can, For he is a Wit, and a vast Cunning Man.

65 Derry, \&c.

Sir, would you succeed him? pray let us dispute, Obedience and Silence, answer'd the Duke; The King turn'd about, and he smil'd for to hear, That the Duke would partake of Robin's Stolen Deer. Derry, \&c.

I guess what your Grace, now, does mean, very plain, 
Basdeo - "A Critical Edition of Little John's Answer to Robin Hood and the Duke of Lancaster (1727)" 25

If Robin's a Thief, sir, You would be the same;

I may as well have my Keeper, a R------- that I know,

Sir, You have your Answer, and so you may go.

75

Derry, \&c. 


\section{NOTES}

[titlepage]

[titlepage] Lancaster]

[titlepage] Canterbury]

2

3

6
I have retained the spelling, capitalization, and italicization of the title which appears on the front of the ballad.

The sister ballad to Little John's Answer entitled Robin Hood and the Duke of Lancaster is available in the following places: Robin Hood and the Duke of Lancaster. A Ballad to the Tune of The Abbot of Canterbury (London: T. White, 1727), 4pp. Leeds, Brotherton Library Special Collections BC Lt q/WAL/L; John Mathew Gutch, A Lytell Geste of Robin Hode, 2 vols. (London: Longman, 1847), 1:397-400; The Life and Exploits of Robin Hood; and Robin Hood's Garland (Halifax: Milner and Sowerby, 1859), ccxlvi-ccxlviii; R. B. Dobson \& J. Taylor, ed., Rymes of Robyn Hode: An Introduction to the English Outlaw, 3rd ed. (Stroud: Sutton Publishing, 1997),191-194.

The full title usually given is King John and the Abbot of Canterbury (Child Ballads no. 4, and Roud Folk Song Index 302). For a modern critical edition see Arthur Quiller Couch, ed., The Oxford Book of Ballads, 6th ed. (Oxford: Clarendon Press, 1941), 849-853.

Perhaps an acknowledgment on the part of the ballad's author that this is not a genuine Robin Hood ballad. Indeed, the Duchy of Lancaster was not created until 1351, a full century and a half after the events in this ballad.

The royal Duchy of Lancaster is in the County of Lancashire.

Nicholas Lechmere was the Chancellor of the Duchy of Lancashire, hence the Duke of Lancaster in the ballad. See A. A. Hanham, "Lechmere, Nicholas, Baron Lechmere (1675-1727)," in The Oxford Dictionary of National Biography (Oxford: Oxford University Press, 2004), http://www.oxforddnb.com/view/article/16262, Accessed 8 Oct 2015.

There appear to be no contemporary references to Lechmere's stature in contemporary sources, which suggests that it refers to the fact that, with Lechmere being a member of the rival Whig faction in the Commons, he was of diminished importance compared to Walpole. His being "bold," as an older edition of The Oxford Dictionary of National Biography indicates, probably refers to the fact that he was "of a temper violent, proud, and 
impracticable." See “Lechmere, Nicholas, Lord Lechmere (16751727)," in The Oxford Dictionary of National Biography, ed. Leslie Stephen, 63 vols. (London: Smith, Elder \& Co. 18851900), 32:336.

Lechmere was "a good lawyer, a quick and distinguished orator, much courted by the Whig party," but unable, it seems, to master the subtlety of temper required for being a good politician. See Edward Pearce, The Great Man: Sir Robert Walpole: Scoundrel, Genius and Britain's First Prime Minister (London: Pimlico, 2006), 108.

Lechmere was elevated to the Peerage on 25 August 1721. See Clive Jones, A Pillar of the Constitution: The House of Lords in British Politics, 1640-1784 (London: Bloomsbury, 1989), 89.

Walpole was accused of "keeping the king to himself, and for permitting none to approach his person who might tell unwelcome truths,” Coxe, Memoirs, 252-53.

The dwarf also appears in Robin Hood and the Duke of Lancaster. These references are perhaps an allusion to Christian Ulrich Jorrey "a Polish dwarf [...] presented to George I as a gift, from the Duke of Saxe Gotha [...] Despite his small stature, Ulrich had an immensely loud, foundation-shaking voice, almost deafening enough 'to endanger the Royal Palace at full volume.' Sometimes he wore Turkish dress, sometimes a fur-trimmed Polish cap. Ulrich also benefitted from English and painting lessons at the King's expense, and had his own servants.” Lucy Worsley, Courtiers: The Secret History of the Georgian Court (London: Faber \& Faber, 2010), 78.

38 Per]

The printer may have made a mistake here, and the word is probably intended to be "pet” instead. I say this because the only reference I have managed to find in the eighteenth century to a similar word indicating agitation comes from a description of the satirist Richard Steele once being described as being "in a damned confounded pet." Cited in Charles A. Knight, A Political Biography of Richard Steele (London: Pickering and Chatto, 2009), 24. Furthermore, there is a scene in Sir Walter Scott's The Antiquary (1816) which refers to "cases of pet" when Sir Arthur Wardour is agitated. See Walter Scott, The Antiquary, 3 vols. (Edinburgh: James Ballantyne, 1816), 1:141. Moreover, "pet" would rhyme with the next line which ends in "sweat." 
directed at the Walpole regime, and Walpole's detractors in both Parliament and the Press asserted that his government was "fundamentally corrupt," often siphoning off money into their own pockets; see Philip Woodfine, "Tempters or Tempted: The Rhetoric and Practice of Corruption in Walpolean Politics," in Corrupt Histories, ed. Emmanuel Kreike and William Chester Jordan (Rochester: University of Rochester Press, 2005), 167-96 at 167. Although both Walpole and Lechmere were Whigs, they were members of rival factions. The fact that the Duke of Lancaster is not sharing in the "cheer" of ill-gotten gains probably suggests that Lechmere is bitter over not being part of Walpole's clique.

"Thieves and receivers are much of a sect" is perhaps an allusion to Jonathan Wild (1683-1725), the self-styled “Thief Taker General of Great Britain” who functioned as London's chief lawenforcement officer but was also the head of a vast organised crime network in London. The phrase "But Robin Hood's cunning, he's none of the gang” seems also to imply this; Wild, though he was the head of a network of criminals, was never seen to be associated with his henchmen. Walpole was equated on a number of occasions with Wild in contemporary popular culture, such as in the character of Peachum, in John Gay's The Beggar's Opera (1728), and Henry Fielding's The Life and Death of Mr. Jonathan Wild the Great (1743). See Moore, The Thieves' Opera.

This may be an allusion to the fact that, despite multiple allegations of fraud and corruption, none of Walpole's accusers could ever tie any concrete evidence of financial mismanagement to him. See Paul Langford, A Polite and Commercial People: England, 1727-1783, New Oxford History of England (Oxford: Oxford University Press, 1989), 21-22.

56 Harry Gambol] The contemporary sobriquet for Bolingbroke. 


\section{BIBLIOGRAPHY}

A Catalogue and Particular Description of the Human Anatomy in Wax-Work, and Several Other Preparations to be Seen at the Royal-Exchange. London: T. White, 1736.

Advice to Dr. Harry Gambol, Upon the Pulling Down of his Stage, Given by his Abused Patient. London: Printed for A. B---tr, one who has had expensive Experience of the Doctor's Barbarous Practice, c.1715(?). Bodleian Library Broadside Ballads Bod16306.

Bambridge and H---g---ns's Petition to a Certain Great Knight. London: Prinded [sic] for J. Thompson, near the Std, c.1730(?). Bod16296.

"Bravery: The Characteristic of an Englishman.” The Gentleman's Magazine and Historical Chronicle, June 1738.

Cleary, Thomas R. Henry Fielding: Political Writer. Waterloo, ON: Wilfrid Laurier University Press, 1984.

The Congress of Excise-Asses. Or Sir B---ue S---ng's Overthrow: A New Ballad. London: Printed for Mr. Nichols, and sold at the pamphlet shops, 1733. Bodleian Library Broadside Ballads Bod6078.

Couch, Arthur Quiller, ed. The Oxford Book of Ballads. 6th ed. Oxford: Clarendon Press, 1941.

Cowan, Brian William. The Social Life of Coffee: The Emergence of the British Coffeehouse. New Haven: Yale University Press, 2005.

Coxe, William. Memoirs of the Life and Administration of Sir Robert Walpole, Earl of Orford. 1798; reprinted London: Longman, 1816.

Dickinson, H. T. “St John, Henry, styled first Viscount Bolingbroke (1678-1751).” In The Oxford Dictionary of National Biography (Oxford: Oxford University Press, 2004) http://www.oxforddnb.com/view/article/24496, accessed April 8, 2015.

Dobson, R. B., and J. Taylor, ed. Rymes of Robyn Hood: An Introduction to the English Outlaw, 3rd ed. Stroud: Sutton Publishing, 1997.

Downie, J. A. A Political Biography of Henry Fielding. London: Routledge, 2009.

Erskine-Hill, Hoawrd. "Pope and the Poetry of Opposition.” In The Cambridge Companion to Alexander Pope, edited by Pat Rogers, 134-49. Cambridge: Cambridge University Press, 2007.

Gatrell, Vic. City of Laughter: Sex and Satire in Eighteenth-Century London. London: Atlantic Books, 2007.

Gay, John. The Beggar's Opera. As it is Acted at the Theatre Royal in Lincolns-Inn-Fields. London: John Watts, 1727.

Goldgar, Bertrand A. Walpole and the Wits. Lincoln, NE: University of Nebraska Press, 1976.

Griffin, Dustin. Swift and Pope: Satirists in Dialogue. Cambridge: Cambridge University Press, 2010.

Gutch, John Mathew. A Lytell Geste of Robin Hode. 2 vols. London: Longman, 1847.

Habermas, Jurgen. The Structural Transformation of the Public Sphere: An Inquiry into a Category of Bourgeois Society. Translated by Thomas Burger and Frederick Lawrence. Cambridge: Polity, 2002. 
Hanham, “Lechmere, Nicholas, Baron Lechmere (1675-1727).” In Oxford Dictionary of National Biography. Oxford: Oxford University Press, 2004), http://www.oxforddnb.com/view/article/16262, accessed April 4, 2015.

Hitchcock, Tim, Sharon Howard, and Robert Shoemaker. "Apprenticeship Indentures and Disciplinary Cases (IA).” In London Lives, 1690-1800, www.londonlives.org, accessed October 14, 2015.

Hoppit, Julian. A Land of Liberty? England, 1689-1727. Oxford: Oxford University Press, 2000.

A Hue and Cry After the Lord B---k or Young Perkin Glad to See his Friends. London: London; Printed in the year 1715. Bodleian Library Broadside Ballads Bod6404.

Jones, Clive. A Pillar of the Constitution: The House of Lords in British Politics, 1640-1784. London: Bloomsbury, 1989.

Knight, Charles A. A Political Biography of Richard Steele. London: Pickering and Chatto, 2009.

The Knight and the Prelate: A New Ballad. London: Printed for P. Holder, near St. James's, 1734. Bodleian Library Broadside Ballads Bod23066.

Lane, Joan. Apprenticeship in England, 1600-1914. London: University College London Press, 1996.

Langford, Paul. The Eighteenth Century: A Very Short Introduction. Oxford: Oxford University Press, 2000.

. A Polite and Commercial People: England, 1727-1783. New Oxford History of England. Oxford: Oxford University Press, 1989.

“Lechmere, Nicholas, Lord Lechmere (1675-1727)." In The Oxford Dictionary of National Biography. Edited by Leslie Stephen. 63 vols. London: Smith, Elder \& Co. 18851900. 32:336.

The Life and Exploits of Robin Hood; and Robin Hood's Garland. Halifax: Milner and Sowerby, 1859.

Little John's Answer to Robin Hood and the Duke of Lancaster. A Ballad. To the Tune of The Abbot of Canterbury. London: T. White, Chancery Lane, 1727. Leeds, Brotherton Library BC Lt q/WAL/L.

Moore, Lucy. The Thieves’ Opera. London: Penguin, 1997.

Oakleaf, David. A Political Biography of Jonathan Swift. London: Pickering and Chatto, 2008.

Parry, Mike . “Thomas White.” In British Book Trade Index http://www.bbti.bham.ac.uk/Detailswithsource.htm?TraderID=94262, accessed October 13, 2015.

Pearce, Edward. The Great Man: Sir Robert Walpole: Scoundrel, Genius and Britain's First Prime Minister. London: Pimlico, 2006.

Percival, Milton B. Political Ballads Illustrating the Administration of Sir Robert Walpole. Oxford: Clarendon Press, 1916.

Plomer, Henry R., et al. A Dictionary of all the Booksellers Who Were at Work in England, Scotland, and Ireland between 1688 and 1725. Oxford: Printed for the Bibliographical Society, 1922.

Richardson, John. “John Gay, The Beggar's Opera, and Forms of Resistance.” EighteenthCentury Life 24, no. 3 (2000): 19-30. 
Robin and Will; or, The Millers of Arlington. A New Ballad. London: Printed for W. Webb, near the Royal-Exchange; and sold by the booksellers of London and Westminster, 1733. Bodleian Library Broadside Ballads Bod4943, http://ballads.bodleian.ox.ac.uk/view/edition/4943.

Robin's Reign; or, Seven's the Main. London: Sold by the Printsellers of London and Westminster, 1731. London, British Museum BM Satires 1868,0808.3541.

Rogers, Pat. Hacks and Dunces: Pope, Swift, and Grub Street, 2nd ed. London: Methuen, 1980.

Scott, Walter. The Antiquary. 3 vols. Edinburgh: James Ballantyne, 1816.

Shepherd, Leslie. The History of Street Literature. Newton Abbot: David Charles, 1973.

Urstad, Tone Sundt. Sir Robert Walpole's Poets: The Use of Literature as Pro-government Propaganda, 1721-1742. Newark: University of Delaware Press, 2000.

Thackeray, William Makepeace. Rebecca and Rowena. London: Hesperus, 2002.

Weinbrot, Howard D. Eighteenth-Century Satire: Essays on Text and Context from Dryden to Peter Pindar. Cambridge: Cambridge University Press, 1988.

Wilson, Katherine. The Sense of the People: Politics, Culture and Imperialism in England, 1715-1785. Past and Present Publications. Cambridge: Cambridge University Press, 1998.

Woodfine, Philip. "Tempters or Tempted: The Rhetoric and Practice of Corruption in Walpolean Politics.” In Corrupt Histories, edited by Emmanuel Kreike and William Chester Jordan, 167-96. Rochester, NY: University of Rochester Press, 2005.

Worsley, Lucy. Courtiers: The Secret History of the Georgian Court. London: Faber \& Faber, 2010. 